Int. J. Dev. Biol. 52: 365-370 (2008)

doi: $10.1387 / \mathrm{ijdb} .072362 \mathrm{~mm}$

\title{
Prolonged human/sheep cellular chimerism following transplantation of human hemopoietic stem cells into the ewe celomic cavity
}

\author{
MONICA MICHELINI ${ }^{1}$, SANDRA PAPINI ${ }^{1}$, ALFREDO ROSELLINI ${ }^{1}$, GIUSEPPE NOIA ${ }^{2}$, MARIA S. LIGATO ${ }^{2}$, \\ SALVATORE MANCUSO ${ }^{2}$, ANDREA CAVAZZANA ${ }^{3}$, GLORIA BERTACCA ${ }^{3}$, CLAUDIO DI CRISTOFANO ${ }^{3}$, \\ RICCARDO SACCARDI ${ }^{4}$, SERENA URBANI ${ }^{4}$ and ROBERTO P. REVOLTELLA ${ }^{1, *}$

\begin{abstract}
${ }^{1}$ Foundation O.N.L.U.S. "Stem Cells and Life", Pisa and Institute of Biomedical Technologies, C.N.R., Unit of Pisa, ${ }^{2}$ Department of Obstetric and Gynecology, Catholic University, Rome, ${ }^{3}$ Department of Oncology, Transplantation and Advanced Technology in Medicine, University of Pisa, Pisa and ${ }^{4}$ Bone Marrow Transplantation Unit, Careggi Hospital, Florence, Italy
\end{abstract}

\begin{abstract}
We evaluated the possibility of prolonged chimerism formation in fetus and lamb, following human cord blood-selected $\mathrm{CD}_{133^{+}}$hemopoietic stem cell (HSC) transplantation into the celomic cavity of ewes at a pre-immune fetal age (44-45 days of pregnancy). Nineteen ewes were injected with HSC and 5 controls with a saline solution. By PCR, HLA-DQ $\alpha 1$ and 6 human microsatellites (CODIS) were used for HSC traceability. FISH analysis was performed with 8 human DNA probes from different chromosomes, to confirm chromosomal integrity, nuclear DNA localization and donor DNA identification. Immunological staining for revealing HLA-DQ $\alpha 1$ expression demonstrated multilineage engraftment. Both HLA-DQ $\alpha 1$ and microsatellites were detected in different tissues of 3 available aborted fetuses, to a lesser extent in 11 lambs tested at 2-months, but not 12-months after birth. Although only 1 fetus of siblings of each sheep was injected, all siblings revealed positive engraftments. Microsatellite analysis showed evidence of human allele segregation in different tissues of individual fetuses and lambs. FISH analysis confirmed chimerism and the presence of human chromosomes. Non-detection of some human gene sequences in different chromosomes and random finding of allele segregation for some human heterozygous microsatellites were found in different tissues of individual animals. Controls born from un-transplanted ewes never revealed any human DNA sequences nor HLADQ $\alpha 1$ expression.
\end{abstract}

KEY WORDS: cord blood, CD133+ cell, celomic cavity, transplantation, chimerism

\section{Introduction}

Sustained in vivo stem cell transplantation represents a major clinical step forward in the management of patients with congenital, hematological, metabolic and immunological disorders (Troeger et al., 2006). Large animal non-injury models enable investigating the feasibility and outcome of purified multilineage stem cell transplantation in parallel with optimizing the recipient's microenvironment, increasing engraftment (Gammaitoni et al., 2003; Westgren, 2006; Troeger et al., 2006). The sheep/human xenogeneic in utero transplantation performed in pregnant ewes at a pre-immune fetal age up to 70 days after fertilization is a promising method for evaluating the engraftment potential of human fetal HSC in vivo (Almeida-Porada et al., 2004; Westgren, 2006). HSC from human cord-blood were injected into the fetal peritoneal cavity in early gestation at 57-67 days. This procedure allows successful HSC engraftment, survival and efficient distribution throughout the body of the fetus. Recently, a novel successful route of human HSC engraftment, employing transplantation of HSC into the celomic cavity of pregnant ewes early in gestation (40-46 days), has been described (Noia et al., 2003).

Abbreviations used in this paper: HSC, hemopoietic stem cells; PCR, polymerase chain reaction; FISH, fluorescence in situ hybridization; STR, short term repeat.

\footnotetext{
*Address correspondence to: Roberto P. Revoltella, M.D., Ph.D. Via L. L. Zamenhof 8, 56127 Pisa, Italy.

Fax:(+39)-050-221-8606. e-mail: rrevoltella@yahoo.it ; roberto.revoltella@itb.cnr.it
}

Accepted: 14th January 2008. Published online: 27th February 2008. 
Our present work aimed to further investigate the engraftment and ultimate fate of human cord blood-selected HSC, after transplantation into the celomic cavity of pregnant ewes at 45-46 daygestation. At variance with these previous studies, where human CD34+ HSC were transplanted to ewes, in the present work we tested cord blood-selected CD133+ HSC because of their high content of more primitive multipotent progenitor cells. Molecular methods were used to confirm whether this model is feasible for generating long-term chimerisms in fetuses and lambs born from these ewes.

\section{Results}

\section{The fate of the engraftment}

CD133+ HSC were injected into the celomic cavity of 19 ewes 45-46 days gestation age (Group A). As control, five ewes were injected with saline solution (Group B). Of the 19 sheep in Group A, 13 underwent miscarriage and 6 delivered a total of 11 lambs, including 3 twins and 1 set of triplets. Among the 5 sheep in Group $B$, one underwent miscarriage after injection with saline solution.

Molecular analyses were performed on either autoptic or bioptic material obtained from 3 spontaneously aborted fetuses, 11 lambs at 2-month post-natal ages and 5 lambs at 12 months after birth.

\section{Analysis of the engraftment}

\section{PCR}

To obtain clear demonstration of the presence of human DNA sequences within fetuses and lambs, and confirm donor DNA identification, the presence of human HLA-DQ $\alpha 1$ and of the 6 human STR was investigated in various fetal (skin, spleen, lung, liver, heart and eye) and lamb tissues (bone marrow, liver, skin) 2 months and 1 year after birth.

Human DNA sequences were detected in all Group A animals (fetuses, 2-month old lambs) but not in lambs after 1 year. All Group B animals were negative.

The representative example shown in Fig. 1A illustrates the results of $P C R$ reactions for human HLA-DQ $\alpha 1$ in tissues analyzed in one fetus and in three 2-month old post-natal lambs transplanted with HSC. By PCR, all these tissues were positive, particularly the skin and liver. In lambs, HLA-DQ $\alpha 1$ was poorly detected in bone marrow (Fig. 1B).

Fig. 1. PCR on sheep samples. (A) Electrophoresis of PCR products obtained from human HLA-DQ $\alpha 1$ gene amplification in fetal tissue and in 3 representative 2-month post-natal lambs. Legend: MW:, 100 bp molecular weight marker; $C_{+}$, positive control (DNA from human CD133+ cells, 242 bp band); $C$-, negative control (DNA from non-injected sheep liver); Sp, spleen; L, liver; He, heart; Sk, skin; Lu, lung; Ey, eye; BM, bone marrow. (B-D) Electropherograms of human short term repeat (STR) in fetal and lamb tissues. (B) Detection of D13S317 in various tissues of an aborted fetus (787655/f) by PCR. Legend: bp, base pairs; RFU, relative fluorescent unit. Positive control: human donor cord blood-isolated CD133+HSC. Arrows indicate the length of the human donor alleles. In all tissues only one allele was present and was randomly distributed. (C) Detection of D13S317 in liver of the same fetus, detected by nested PCR. (D) Detection of D13S317 in liver and skin samples of 2-month old lambs, before and after microdissection. The peak (arrow) was identical in the 2 twins (217112 and 217108; see Table 3).

The 6 human STR were detected in all the fetal tissues analyzed. Unlike findings for the post-natal animals, in the 3 aborted fetuses, STR were detected in almost every assayed organ injected with HSC (Table 2). In some cases, (see Fig. 1B, which reports the results of one fetus (787655/f) taken as an example), tissues analyzed by double PCR using the same primers, provided evidence of allele segregation, at 256 and 264 bp respectively (arrows indicate allele sizes in donor DNA) of the heterozygous STR D13S317. The presence of each allele was randomly distributed among the fetal tissues analyzed. Loss of heterozygosity shown in different tissues of the same fetus using the same couple of primers, was confirmed by nested PCR performed using the same DNA but with external primers in the 2 amplification steps (Fig. 1 B,C) followed by sequencing.

In contrast, none of STR was consistently detected in the 2month old lambs: positivity appeared only in a few organs of the same animal, with random distribution. (Table 2). Although the efficiency of STR amplification was not identical for all STR, detection of STR in the liver was better than in other organs (compare L columns in Table 2). CD133+ HSC were transplanted in only one fetus per mother: however human DNA was found in

\section{A}

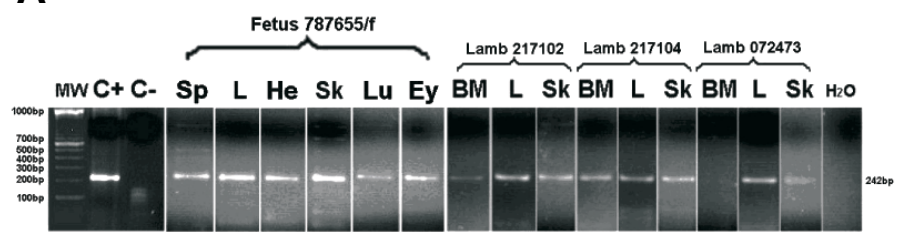

B

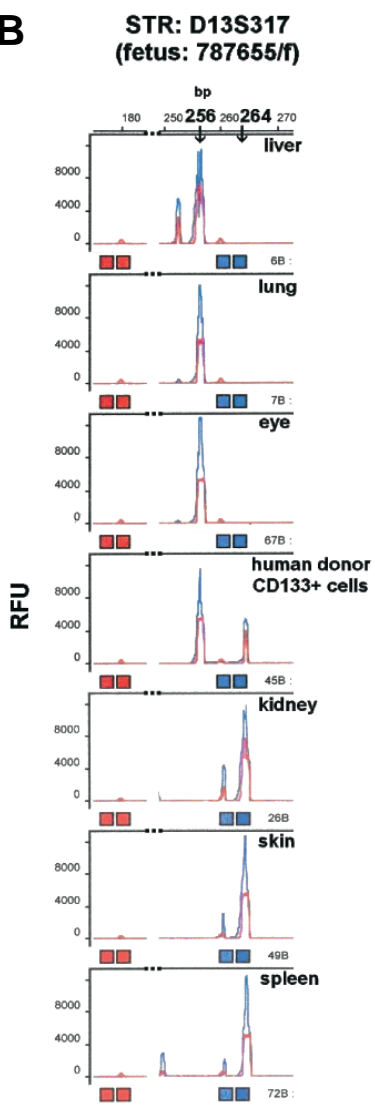

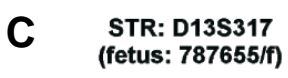
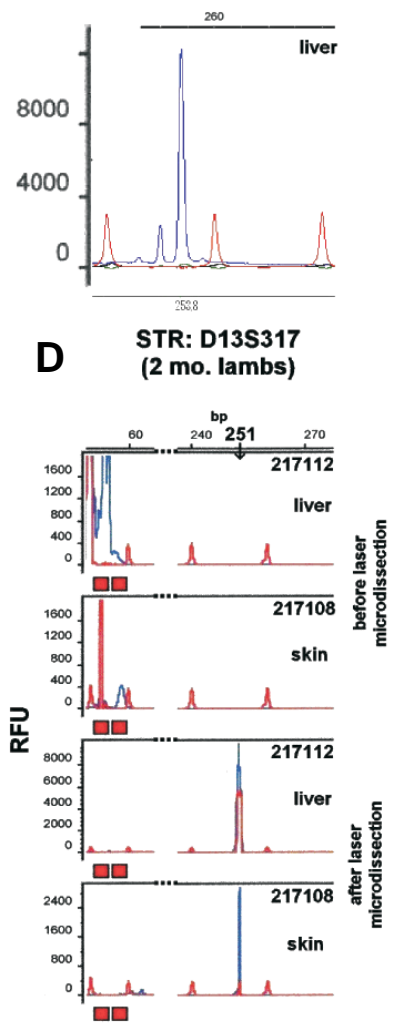
TABLE 1

\section{CHARACTERISTICS OF LOCI INVESTIGATED AND LIST OF THE PRIMERS}

\begin{tabular}{|c|c|c|c|}
\hline $\begin{array}{l}\text { STR } \\
\text { Locus }\end{array}$ & $\begin{array}{l}\text { Chromosomal } \\
\text { location }\end{array}$ & $\begin{array}{c}\text { GeneBank } \\
\text { accession } \\
\text { number }\end{array}$ & $\begin{array}{l}\text { Primer sequence } \\
\text { (all primers A labeled with 6-FAM in 5) }\end{array}$ \\
\hline$\overline{F G A}$ & $4 q 28$ & M64982 & $\begin{array}{l}\text { A-GCCCCATAGGTTTTGAACTCA } \\
\text { B-TGATTTGTCTGTAATTGCCAGC }\end{array}$ \\
\hline VWA & 12p12pter & M25858 & $\begin{array}{l}\text { A-CCCTAGTGGATGATAAGAATAATCAGTATG } \\
\text { B-GGACAGATGATAAATACATAGGATGGATGG }\end{array}$ \\
\hline D13S317 & 13q22-31 & AF250876 & $\begin{aligned} 1^{\text {st }} \text { step: } & \text { A-GTTGCTGGACATGGTATCACAG } \\
& \text { B-TCAGAGAGCTTGAATTGTTGGT } \\
2^{\text {nd }} \text { step: } & \text { A-GAAGTCTGGGATGTGGAGGA } \\
& \text { B-TCCTTCAACTTGGGTTGAGC }\end{aligned}$ \\
\hline D18S51 & $18 q 21.3$ & L18333 & $\begin{aligned} 1^{\text {st }} \text { step: } & \text { A-CAAACCCGACTACCAGCAAC } \\
& \text { B-GAGCCATGTTCATGCCACTG } \\
2^{\text {nd }} \text { step: } & \text { A-GCCATCGCACTTCACTCTGA } \\
& \text { B-AAGGTGGACATGTTGGCTTC }\end{aligned}$ \\
\hline D21S11 & $21 q 11-21$ & M84567 & $\begin{aligned} 1^{\text {st }} \text { step: } & \text { A-ATATGTGAGTCAATTCCCCAAG } \\
& \text { B-TGTATTAGTCAATGTTCTCCAG } \\
2^{\text {nd }} \text { step: } & \text { A-CCCCAAGTGAATTGCCTTCT } \\
& \text { B-AGTCAATGTTCTCCAGAGACAGAC }\end{aligned}$ \\
\hline D8S1179 & $8 q$ & AF250877 & $\begin{array}{c}1^{\text {st }} \text { step: A-TTTTTGTATTTCATGTGTACATTCG } \\
\text { B-CGTATCCCATTGCGTGAATATG }\end{array}$ \\
\hline
\end{tabular}

all the lambs investigated, including twins and triplets born from the same mother (Table 2). This evidence demonstrates effective engraftment of cells containing human DNA among siblings.

One year after injection, human DNA was never detected in any organs or tissue of the lambs (not shown).

\section{FlSH}

In order to evaluate the presence of multiple human chromosomes in single cell nuclei, we performed M-FISH on tissues that by PCR were concomitantly positive for HLA-DQ $\alpha 1$ and at least 2 human microsatellites. Eight DNA probes were employed: 1 pan-centromeric and 1 pan-telomeric mapping on all human chromosomes, 6 mapping on locus-specific sequences of different chromosomes (Table 3 and Fig. 2 A-E). In most tissues analysed, pan-centromeric and pan-telomeric probes hybridized within the same nuclei, by DC-FISH analysis (Fig. 2B see arrows). M-FISH demonstrated positive for cosmidic or alphoid sequences, in fetal and 2-months old lamb tissues (Table 3 and Fig. 2, compare $C, D, E)$. Comparison of 3 different sequences in chromosome 8 showed no CEP 8, while positive signals for LPL (8p22) and c-myc (8q24) were detected in most tissues analyzed (Table $3)$. Fluorescent signals were confined to specific areas: in fetal skin for example, restricted mostly to the basal layer of hair bulbs (Fig. 2D see arrows). Additionally, in all tissues we found capillaries with strong positive signals in the nucleus of a few endothelia cells (Fig. 2E). Interestingly, only a few capillaries within groups hybridized with the human fluorescent probe (Fig. 2E see inset). Although in both cases the proportion of positive cells detected by DC-FISH and M-FISH was low, by DC-FISH pan-centromeric and pan-telomeric signals were generally stronger and more cells were positive than those counted by M-FISH, being significantly higher in the 3 fetuses $(0.5-1.0 \%$ out of 500 cells counted in 5 different sections of the same sample) than in the 2-month old lambs $(<0.01 \%)$ analyzed (not shown).

\section{Immunological staining}

Immunological staining of anti-human HLA-DQ $\alpha 1$ antibodies on different Group A fetal tissue samples frequently revealed positivity, particularly in capillaries. Positive staining was seen in capillaries grouped in the same small areas of tissue (for example the corneal limbus in the eye), near other negative capillaries (Fig. $2 \mathrm{~F}$, see asterisk), demonstrating viable human cells within host tissues, capable of expressing their own genome. A faint immunostaining signal was detected in liver bile ducts and skin hair bulbs (not shown).

\section{Enhanced signal detection after microdissection}

The presence of such a small number of human positive cell nuclei suggested that probably many of the STR-negative samples in lamb tissues could find positive if enriched in specific positive cells. Fig. 1D shows as a representative example the electropherograms of double PCR for STR D13S317 in liver and skin samples of two 2-months lambs (respectively 217112 and 217108).
Fig. 2. FISH and immunological staining. (A-B) DC-FISH (Cambio probes) for human pan-centromeric (red) and pan-telomeric (green) sequences. (A) Human prostatic carcinoma as positive control. (B) $\mathrm{Fe}$ tal sheep liver. The two signals are present in the same nuclei, in few cells. (C,D,E) M-FISH analysis with 3 probes on human chromosome 8 (ProVision ${ }^{\circledR}$ ) (red: LSI-LPL; green: LSI-c-myc; light-blue: CEP8). Yellow dots result from the 2 overlapping red and green signals. Nuclei were counterstained with DAPI. (C) Human prostate carcinoma as positive control revealed the presence of all 3 chromosomal sequences in the nuclei. (D) Skin hair follicle cells showed yellow signals (arrows). (E) Capillary with endothelial cells showing the presence of 2 signals
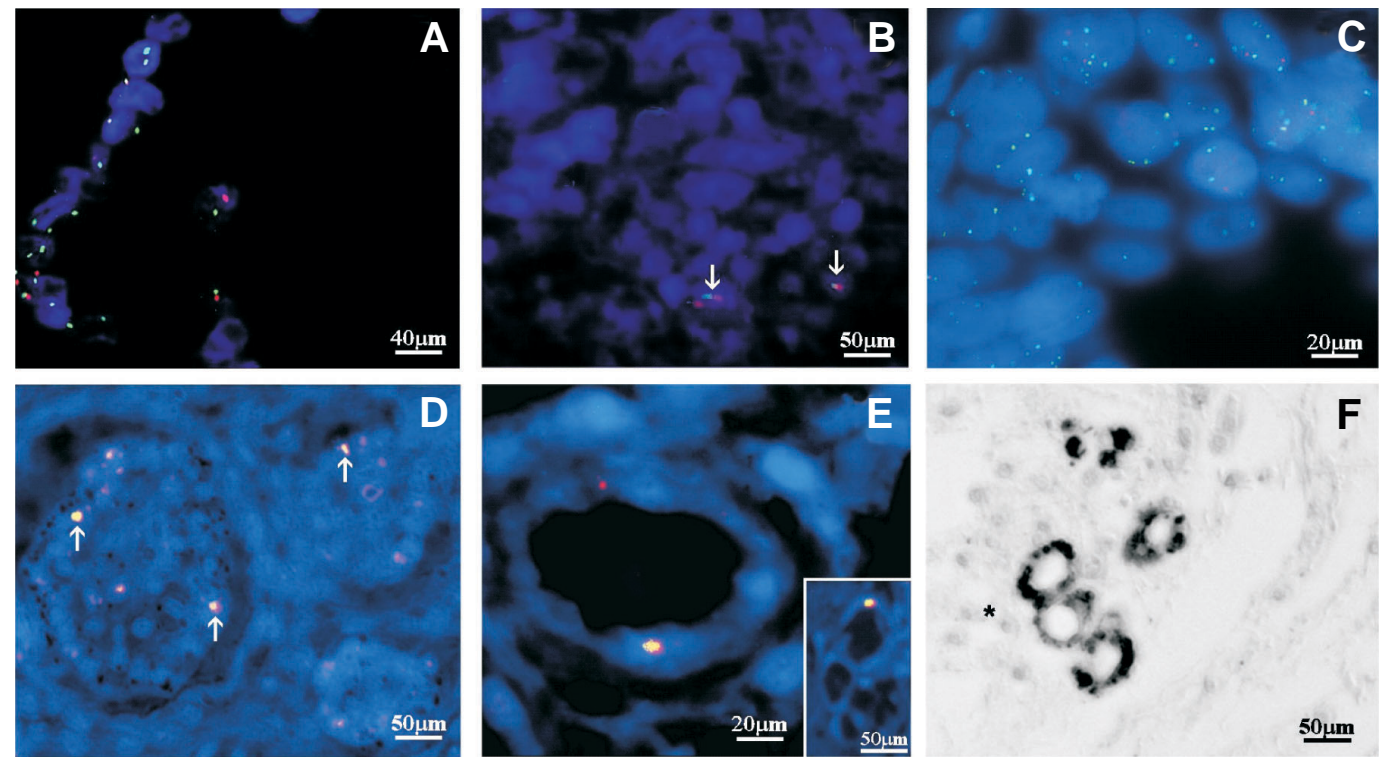

(red, yellow). Inset in (E) shows that the signal is present in only one capillary of a group of 3 in close proximity. (F) Immunological staining for human HLA-DQ 1 antigen (black signals) in capillaries of fetal corneal limbus. Note that several capillaries are HLA-DQ 1 negative (asterisk). 
Since we had detected positive FISH signals in the skin and liver, mainly confined to a few cells in small areas, these same areas were then laser microdissected, genomic DNA was extracted and PCR performed. STR D13S317 became detectable, only with DNA extracted from positive cells selectively enriched after microdissection but was not detected after PCR performed with DNA extracted from the whole original tissue.

\section{Discussion}

The results of our present work show that CD133+ HSC transplanted to ewes into the celomic cavity of 45-46 days gestation ultimately gave rise to: 1 ) high rate of spontaneous abortion (13 out of 19 in group A and 1 out of 5 in group B); 2) a low level of HSC engraftment in different target tissues; 3 ) short-lived human/sheep chimerism easily detected in fetus, but rapidly decreasing at 2 months after birth, with loss of any positive human cells after 12 months; 4) possibility of rare and unstable heterokaryon formation detected in different host tissues.
These results raise several interesting points:

1) The high rate of abortion and the too low level of engraftment agree with results of other groups using sheep/human xenogeneic in utero transplantation methods (Young et al., 2003; Schoeberlein et al., 2004; Oppenheim et al., 2001) but in contrast with other reports documenting higher engraftment levels in sheep (Zanjani et al., 1992; Noia et al., 2003; Gammaitoni et al., 2003). One plausible explanation is that this route of injection is less efficient than in utero transplantation because different HSC, particularly if isolated from different donors and if injected too early to ewes, may not be equally feasible.

2) Little is known about the fate of HSC in the model of xenotransplantation. In fetuses born from transplanted sheep we found evidence of a small but constant presence of chimeric human cells in almost all organs examined; but human DNA detection rapidly decreased post-natally and no evidence was found in lambs 1 year after birth. HLA-DQ $\alpha 1$ was found expressed with higher frequency in endothelial cells and less in other target tissues, particularly in bile ducts in the liver, in the eye, skin and hair follicles. These areas

TABLE 2

PCR AMPLIFICATION OF HUMAN HLA-DQA1 DNA AND 6 HUMAN STR FROM TISSUES OF 2-MONTH POST-NATAL LAMBS BORN FROM EWES INJECTED WITH HUMAN CD133+ HSC

\begin{tabular}{|c|c|c|c|c|c|c|c|c|c|c|c|c|c|c|c|c|c|c|c|c|c|c|c|}
\hline \multirow{3}{*}{ Mother } & & \multirow{3}{*}{ Lambs } & \multicolumn{3}{|c|}{ HLA-DQ $\alpha 1$} & \multicolumn{18}{|c|}{ Human STR } \\
\hline & & & \multirow{2}{*}{ BM } & \multirow{2}{*}{$\mathbf{L}$} & \multirow{2}{*}{ Sk } & \multicolumn{3}{|c|}{ FGA } & \multicolumn{3}{|c|}{ VWA } & \multicolumn{3}{|c|}{ D13S317 } & \multicolumn{3}{|c|}{ D18S51 } & \multicolumn{3}{|c|}{ D 21S11 } & \multicolumn{3}{|c|}{ D8S1179 } \\
\hline & & & & & & BM & $\mathbf{L}$ & Sk & BM & $\mathbf{L}$ & Sk & BM & $\mathbf{L}$ & Sk & BM & $\mathbf{L}$ & Sk & BM & $\mathbf{L}$ & Sk & BM & $\mathbf{L}$ & Sk \\
\hline 707637 & I & 072473 & - & + & + & + & - & - & - & - & - & + & - & + & - & - & - & + & + & - & na & na & na \\
\hline \multirow{2}{*}{072482} & & 217108 & - & + & + & - & + & - & - & + & - & - & - & - & - & - & - & - & + & - & na & + & + \\
\hline & & 217112 & + & na & + & + & na & + & + & na & - & - & na & - & + & na & + & - & na & - & na & + & + \\
\hline 958279 & I & 217107 & - & na & + & - & - & - & - & + & + & - & - & - & + & + & - & - & - & - & na & na & na \\
\hline \multirow{2}{*}{958297} & & 217103 & $\mathrm{Na}$ & + & + & - & + & - & - & + & - & - & + & - & + & - & - & - & + & - & na & na & na \\
\hline & & 217104 & + & + & + & - & - & - & - & - & + & - & - & - & na & + & - & - & - & - & na & na & na \\
\hline \multirow{3}{*}{787668} & & 217109 & - & + & + & - & + & + & - & + & - & - & - & - & - & - & - & - & - & - & na & na & na \\
\hline & & 217110 & - & + & + & - & - & - & - & na & - & - & + & - & - & + & - & - & + & - & na & na & na \\
\hline & & 217111 & $\mathrm{Na}$ & na & + & - & - & + & + & - & + & + & + & + & - & na & + & - & + & - & na & na & na \\
\hline \multirow{2}{*}{072770} & & 217101 & $\mathrm{Na}$ & + & + & - & + & - & - & - & - & - & - & - & - & - & - & - & - & - & na & na & na \\
\hline & & 217102 & + & + & + & - & + & + & - & + & - & - & + & + & - & t & - & - & - & - & na & D & n \\
\hline
\end{tabular}

Legend: Score: HLA-DQ $\alpha 1$ and human STR : +, DNA band of the expected length, verified by sequencing after PCR amplification; -, no DNA amplification detected; na: sample not adequate for DNA analysis. Lambs born from each mother are shown. Tissues: BM, bone marrow; L, liver; Sk, skin.

TABLE 3

M-FISH ANALYSIS PERFORMED ON SKIN, LIVER (BOTH IN FETUS AND LAMB) AND EYE (ONLY IN FETUS)

\begin{tabular}{|c|c|c|c|c|c|c|c|c|}
\hline \multirow[b]{2}{*}{ Probes } & \multirow[b]{2}{*}{ Pan-centromeric } & \multirow[b]{2}{*}{ Pan-telomeric } & \multicolumn{3}{|c|}{ Cosmidic (LSI) } & \multicolumn{2}{|c|}{ Telomeric (TEL) } & \multirow{2}{*}{$\frac{\text { Alphoid (CEP) }}{8}$} \\
\hline & & & LPL & p16 & c-myc & T 12 & T 18 & \\
\hline Chromosomal localization & $\begin{array}{c}\text { Centromeres of all human } \\
\text { chromosomes }\end{array}$ & $\begin{array}{c}\text { Telomeres of all human } \\
\text { chromosomes }\end{array}$ & $8 p 22$ & $9 p 21$ & $8 q 24$ & $12 p$ & $18 p$ & $8 p 11.1-q 11.1$ \\
\hline Hybridization signal & ++ & +++ & + & + & + & ++ & + & - \\
\hline
\end{tabular}

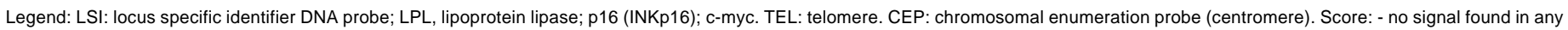
tissue investigated; + to +++: positive signals detected in most tissues analyzed, varying in intensity. 
are known to contain multipotent stem/progenitor cells in vivo (Verfaillie et al., 2000; Spradling et al., 2001). These findings suggest that after transplantation, multipotent HSC migrated to the fetus, renewing themselves and probably a small number of their progeny underwent differentiation in different organs where cellcell interactions and soluble growth factors in an appropriate microenvironment contributed to influenceing self maintenance or differentiation (Navarrete et al., 2000). Migration of CD133+ HSC from the celomic cavity to the fetus at a pre-immune fetal age might induce immunological tolerance. However, HLA class II antigen expression during development could enhance the host immune response against the fetus, reducing the chimerism and ultimately inducing abortion.

3) The incomplete representation of human specific DNA traits detected in lambs after birth as compared to fetuses depended largely on the number of HSC, reflecting different sensitivities for detecting HLA-DQ $\alpha 1$ and the STR. Varying proportions of human and sheep cells, found by comparing different tissues from both fetuses and lambs, might contribute to affecting human DNA detection: however, this problem could often be by-passed with laser microdissection that helped to enrich the relative number of human DNA positive cells locally concentrated in special structures.

4) By FISH, using fluorescent pan-centromeric and pan-telomeric DNA probes, but in some cases also individual alphoid, cosmidic or telomeric DNA probes, multiple positive signals could be detected exclusively in the nucleus of cells. These findings strongly suggest that intact HSC continued to be present, during development both in fetus and post-natal lamb. In contrast we also found rare evidence of exclusion of some gene markers and rare but clear evidence of allelic segregation for some heterozygous STR, in different tissues of the same animal during development, supporting the possibility of partial human DNA engraftment in a small number of endogenous cells leading to unstable heterokaryons formation. When and where DNA loss events might have occurred after human HSC injection into the celomic cavity is unknown. Since we found this evidence early in fetuses, we assume that the events originated after compatible contacts between cells of the 2 species at a very early phase following transplantation. In this case we cannot exclude the possibility of events of cell fusion between host and sheep cells.

It must be stressed that the different molecular methods do not ensure to detect a complete integrity of all chromosomes in all loci, nor they exclude events of transfer of partial DNA fragments from donor to host cells. Microchimerism with clear evidence of hybrid cell formation, resulting in reprogramming of the new cell phenotype with repair and resumption of injured tissues have been recently observed in several different models of xeno-transplantation (Weimann et al., 2003; Kashofer et al., 2006; Revoltella et al., 2008).

These findings support the possibility that cell fusion and cell plasticity may not be mutually exclusive mechanisms of generating chimerism after engraftment, but may represent different modes of adaptation to the host environment.

\section{Materials and Methods}

\section{Human cord blood-selected CD133+ HSC}

Umbilical cord blood was obtained from 6 different informed consenting donors (Bone Marrow Transplantation Unit, Careggi Hospital, Flo- rence). Cord blood-selected CD133+ HSC were obtained using CD133+ Cell Isolation Kit (Miltenyi Biotec $\mathrm{GmbH}$, Gladbach, Germany), following the manufacturer's procedure. The efficiency of purification of CD133+ HSC ranged from $90 \%$ to $94 \%$.

\section{Sheep recipients}

Twenty-four pregnant ewes (Ovis Aries comisana, Center for Animal Breeding and Use of the Catholic University of Rome, Italy) were employed, treated according to protocols approved by the Institutional Review Board of the University of Rome. Transplantation into the celomic cavity was performed on 19 ewes (Group A), as previously described (Noia et al., 2003). Only one fetus of the 2 or 3 siblings of each pregnant sheep was injected with 270,000-647,000 CD133+ HSC. Each ewe was injected with HSC from an individual cord blood. Five control ewes received saline solution alone using the same route of injection (Group B).

\section{Analysis of the engraftment}

\section{$P C R$}

Genomic DNA was extracted from frozen bioptic tissues (for post-natal lambs) or from paraffin embedded sample preparations (for aborted fetuses) according to the manufacturer's protocol (QIAamp DNA Mini Kit, Qiagen $\mathrm{GmbH}$, Hilden, Germany) and analyzed by polymerase chain reaction (PCR) for the presence of human HLA-DQ $\alpha 1$, as marker for human DNA, using the forward (5'-GTG CTG CAG GTG TAA ACT TGT ACC AGT TGT-3') and reverse (5'-CAC GGA TCC GGT AGC AGC GGT AGA AGT TG-3') primers, as described (Almeida-Porada et al., 2002) with only minor modifications (Revoltella et al., 2008) using Taq Platinum (Invitrogen, Merelbeke, Belgium), following the manufacturer's protocols. Usually 1-2 $\mu \mathrm{g}$ of sheep genomic DNA (both Group A and Group B animals) were used in the assay with only one amplification step of 40 PCR cycles. Single positive expected 242 bp PCR bands were sequenced (Big Dye, Terminator V 2.0 Cycle Sequencing Ready Reaction Kit, Applied Biosystem, Foster City, CA, USA) to confirm the human HLADQ 1 DNA sequence. DNA was also tested for inherited DNA polymorphisms by the presence of 6 microsatellites (short tandem repeats, STR, from CODIS, a method largely employed for paternity testing and noninvasive prenatal diagnostic applications (Ricci et al., 2000; Cha et al., 2005)), for HSC traceability and for excluding sample or operational contaminations.

To establish the sensitivity of the PCR amplification method on sheep samples, standard curves of dilution limit were run for human DNA from cord blood mononuclear cells (MNC) diluted with untreated sheep liver genomic DNA, up to a total of $1 \mu \mathrm{g}$ DNA. With only one amplification step of 40 PCR cycles, $1 \mathrm{pg}$ of human MNC DNA could be detected in $1 \mu \mathrm{g}$ of total human plus sheep DNA.

DNA was also tested for the presence of 6 human STR (D13S317, vWA, FGA, D8S1179, D18S51, D21S11. STR detection was performed as a double PCR, using the same couple of primers (see Table 1). To further confirm the presence of the STR observed and exclude contaminations, we performed for three STR (D18S51, D21S11 D13S317) a nested PCR with different external primers as reported in Table 1. Each PCR was performed in duplicate. All forward primers were labeled with 6FAM fluorochrome. Positive fluorescent bands of the expected length recovered after gel electrophoresis were confirmed by sequencing. STR demonstrated a different sensitivity. STR amplified once showed a range of sensitivity varying from $0.1 \mathrm{pg}$ (D8S1179) to $10 \mathrm{pg}$ (D13S317) of human DNA plus $1 \mu \mathrm{g}$ of sheep DNA. Double step PCR, using the same primers, improved sensitivity at $4^{\text {th }}$ order of magnitude $\left(10^{4}\right)$.

FISH

Chromosomic DNA integrity was evaluated by fluorescent in situ hybridization (FISH) analysis, looking for 8 different genes present in different human chromosomes.

Formalin fixed, paraffin embedded tissue from biopsies and proved by 
PCR to contain the HLA-DQ $\alpha 1$ gene, were subjected to single-color or dual-color FISH analysis (DC-FISH Cambio, Cambridge, United Kingdom) and multi-color FISH analysis (M-FISH Vysis, ABBOTT Laboratories, Abbott Park, Illinois, USA). Eight DNA probes were employed. For DC-FISH, 1 pan-centromeric and 1 pan-telomeric probe, each mapping on all human chromosomes, were labeled with 2 different fluorescent colors. For M-FISH, 3 probes, differently labeled and mapping on different chromosomes, and 3 probes mapping on chromosome 8, were used (Table 2). M-FISH with Vysis probes was performed as described (Sato et al., 1999). DC-FISH analysis, with Cambio probes, was performed according to the manufacturer's instructions as reported in www.cambio.co.uk.

In some cases even though negative by PCR, samples revealed FISH positive small cell aggregates, in restricted areas, for the specific DNA probe investigated. DNA was then prepared after careful laser microdissection of these positive areas (usually 200-400 cells) (Okuduco et al., 2005), and tested again by PCR, to verify primitive negative or confirm poorly positive evidence. Chimerism was accepted when samples were positive for HLA-DQ $\alpha 1$, three STR and FISH.

\section{$H L A-D Q \alpha 1$ immunological staining}

Sections from paraffin embedded blocks were processed for immunoperoxidase staining to detect $\mathrm{HLA}-\mathrm{DQ} \alpha 1$ with the monoclonal antibody anti-human HLA-DP, DQ, DR antigen (clone CR3/43, DAKO-Cytomation Glostrup, Denmark), performed following manufacturer's instructions.

\section{Acknowledgments}

Preliminary data were presented at the: VII International Meeting: "In utero stem cell transplantation: new frontiers in regenerative therapy", Rome, Italy, October 6th-gth, 2004; Symposium:"Stem Cell Biology \& Technology I. "The th Royan International Research Congress on Reproductive Medicine and Stem Cells". Teheran, Iran. 13 th $-15^{\text {th }}$ September 2006; Symposium "Stem cell differentiation and cancer" $14^{\text {th }}$ Conference of the International Society of Differentiation. Innsbruck, Austria, th $-11^{\text {th }}$ October 2006. Grant sponsors: Italian Ministry of Health (Project "Stem 2001"); M.I.U.R. (FIRB: "New Medical Engineering" and "Technologies in Oncology"); Joint Project "Kontakt" between the Foreign Ministries of Italy and Czech Republic.

\section{References}

ALMEIDA-PORADA G., EL SHABRAWY D., PORADA C., ZANJANI E.D. (2002). Differentiative potential of human metanephric mesenchymal cells. Exp Hematol. 30: 1454-1462.

ALMEIDA-PORADA G., ZANJANI E.D. (2004). A large animal noninjury model for study of human stem cell plasticity. Blood Cells Mol Dis. 32: 77-81.

CHA D.H., KROSROTEHRANI K., BIANCHI D., JOHNSON L. (2005). The utilità of an erythroblast scorino system and gender-independent short tandem repeat (STR) analysis for the detection of aneuploid fetal cells in maternal blood. Prevent Diagn. 25: 586-591.

GAMMAITONI L., BRUNO S., SANAVIO F., GUNETTIM., KOLLETO., CAVALLONI G., FALDA M., FAGIOLI F., LAPIDOT T., AGLIETTA M., PIACIBELLO W. (2003). Ex vivo expansion of human adult stem cells capable of primary and secondary hemopoietic reconstitution. Exp Hematol. 31:261-70.

YOUNG A.J., HOLZGREVE W., DUDLER L., SCHOEBERLEIN A., SURBEK D.V. (2003). Engraftment of human cord blood-derived stem cells in preimmune ovine fetuses after ultrasound-guided in utero transplantation. Am J Obstet Gynecol. 189:698-701.

KASHOFER K., SIAPATI EK., BONNET D. (2006). In vivo formation of unstable heterokaryons after liver damage and hematopoietic stem cell/progenitor transplantation. Stem Cel/s 24:1104-12.

NAVARRETE C.V. (2000). The HLA system in blood transfusion. Baillieres Best Pract Res Clin Haematol. 13:511-32.

NOIA G., PIERELli L., BONANNO G., MONEGO G., PERILLO A., RUTELLA S., CAVALIERE AF., DE SANTIS M., LIGATO MS., FORTUNATO G., SCAMBIA G., TERZANO GM., IANNACE E., ZELANO G., MICHETTI F., LEONE G., MANCUSO S. (2003). A novel route of transplantation of human cord blood stem cells in pre-immune fetal sheep: the intracelomic cavity. Stem Cel/s 21: 638-646.

OKUDUCO A.F., HAHNE J.C., VON DEIMLING A., WERNERT N. (2005). Laserassisted microdissection, techniques and applications in pathology. Int. J. Mol Med. 15: 763-769.

OPPENHEIM S.M., MUENCH M.O., GUTIERREZ-ADAN A., MOYER A.L., BONDURANT R.H., ROWE JD., ANDERSON G.B. (2001). Hematopoietic stem cell transplantation in utero produces sheep-goat chimeras. Blood Cells Mol Dis. 27:296-308.

REVOLTELLA R.P., PAPINI S., ROSELLINI A., MICHELINI M., FRANCESCHINI V., CIORBA A., BERTOLASO L., MAGOSSO S., HATZOPOULOS S., LORITO G., GIORDANO P., SIMONI E., OGNIO E., CILLI M., SACCARDI R., URBANI S., JEFFERY R., POULSOM R., MARTINI A. (2008). Cochlear repair by transplantation of human cord blood CD133+ cells to NOD-SCID mice made deaf with kanamycin and noise. Cell Transplant. (in press).

RICCI U., SANI I., GUARDUCCI S., BIONDI C., PELAGATTI S., LAZZERINI V., BRUSAFERRI A., LAPINI M., ANDREUCCI E., GIUNTI L., GIOVANNUCCI UZIELLI M.L. (2000). Infrared fluorescent automated detection of thirteen short tandem repeat polymorphisms and one gender-determining system of the CODIS core system. Electrophoresis 21: 3564-3570.

SATO K., QIAN J., SLEZAK J.M., LIEBER M.M., BOSTWICK D.G., BERGSTRALH E.J., JENKINS R.B. (1999). Clinical significance of alterations of chromosome 8 in high-grade advanced, nonmetastatic prostate carcinoma. J. Nat/ Cancer Inst. 91: 1574-1580.

SPRADLING A., DRUMMOND-BARBOSA D., KAI T. (2001). Stem cells find their niche. Nature 414: 98-104.

SCHOEBERLEIN A., HOLZGREVE W., DUDLER L., HAHN S., SURBEK D.V. (2004). In utero transplantation of autologous and allogeneic fetal liver stem cells in ovine fetuses. Am J Obstet Gynecol. 191:1030-6.

TROEGER C., SURBEK D., SCHOBERLEIN A., SCHATT S., DUDLER L., HAHN S., HOLZGREVE W. (2006). In utero haematopoietic stem cell transplantation. Experiences in mice, sheep and humans. Swiss Med Wkly. 136:498-503.

VERFAILLIE C.M., ALMEIDA-PORADA G., WISSINK S., ZANJANI E.D. (2000). Kinetics of engraftment of CD34(-) and CD34(+) cells from mobilized blood differs from that of CD34(-) and CD34(+) cells from bone marrow. Exp Hematol. 28: 1071-1079.

WEIMANN J.M., JOHANSONN C.B., TREJO A., BLAU H.M. (2003). Stable reprogrammed heterokaryons form spontaneously in Purkinje neurons after bone marrow transplant. Nat Cel/ Biol. 5: 959-66.

WESTGREN M. (2006). In utero stem cell transplantation. Semin Reprod Med. 24: 34857.

ZANJANI E.D., PALLAVICINI G., ASCENSAO J.L., FLAKE A.W., LANGLOIS R.G., REITSMA M., MACKINTOSHF.R., STUTESD., HARRISON M.R., TAVASSOLI M.(1992). Engraftment and long-term expression of human fetal hemopoietic stem cells in sheep following transplantation in utero. J Clin Invest. 89:11781788 . 


\section{Related, previously published Int. J. Dev. Biol. articles}

See our recent Special Issue Ear Development edited by Fernando Giraldez and Bernd Fritzsch at: http://www.ijdb.ehu.es/web/contents.php?vol=51\&issue=6-7

See our Special Issue Mammalian Reproduction \& Development in honor of Anne McLaren and edited by Brigid Hogan at: http:// www.ijdb.ehu.es/web/contents.php?vol=45\&issue $=3$

Human conjunctival epithelial precursor cells and their progeny in 3D organotypic culture

Alfredo Rosellini, Sandra Papini, Claudio Giannarini, Marco Nardi and Roberto P. Revoltella

Int. J. Dev. Biol. (2007) 51: 739-743

alphallb integrin, a novel marker for hemopoietic progenitor cells Catherine Corbel Pierre Vaigot and Josselyne Salaün

Int. J. Dev. Biol. (2005) 49: 279-284

Incorporation of cultured embryonic cells into transgenic and chimeric, porcine fetuses.

E Notarianni, S Laurie, A NG and K Sathasivam

Int. J. Dev. Biol. (1997) 41: 537-540

Reflections on the biology of embryonic stem (ES) cells.

$\mathrm{R} L$ Gardner and F A Brook

Int. J. Dev. Biol. (1997) 41: 235-243

Stromal cells from murine developing hemopoietic organs: comparison of colony-forming unit of fibroblasts and long-term cultures.

R Van den Heuvel, E Mathieu, G Schoeters, H Leppens and O Vanderborght Int. J. Dev. Biol. (1991) 35: 33-41

2006 ISI **Impact Factor $=3.577^{\star *}$

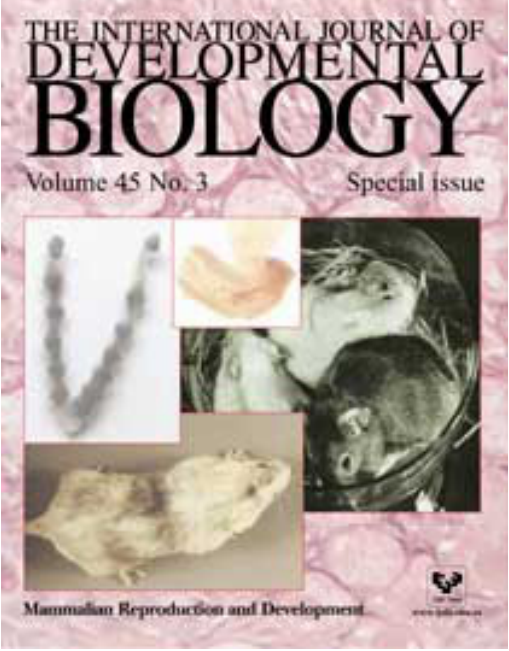

